\title{
Two new species of Begonia L. (Begoniaceae) from central Laos
}

\author{
L. V. Averyanov ${ }^{1}$, Khang Sinh Nguyen ${ }^{2}$, T. V. Maisak ${ }^{1}$, Hiep Tien Nguyen ${ }^{3}$, Hieu Quang Nguyen ${ }^{3}$ \\ ${ }^{1}$ Russian Academy of Sciences, Komarov Botanical Institute, Prof. Popov str., 2, St.-Petersburg, 197376, Russian Federation. \\ E-mails:av_leonid@mail.ru,tmaisak@mail.ru \\ ${ }^{2}$ Institute of Ecology and Biological Resources, Vietnam Academy of Science and Technology, 18, Hoang Quoc Viet Road, \\ Nghia Do, Cau Giay district, Hanoi, Vietnam.E-mail: nskhang@gmail.com \\ ${ }^{3}$ Center for Plant Conservation, Vietnam Union of Science and Technology Associations, № 25/32, lane 191, Lac Long Quan Rd, \\ Nghia Do, Cau Giay district, Hanoi,Vietnam.E-mail: centerforplantconservation@gmail.com
}

Keywords: Begonia, Begoniaceae, Laos, local endemism, new species, plant diversity, plant taxonomy.

Summary. Begonia comprises at least 1850 species, most of which are local endemics. The greatest genus diversity is observed in tropical zone of America and Asia with particular rich area in Indochinese Peninsula. Meanwhile, the inventory of the genus in this region remains far from acceptable completing. Until recently, only 20 species were documented in Laos. Two more species are described here. Both are local endemics found in small sporadic limestone formations in central Laos. The first species, B. quadripetiolata (expectedly sect. Platycentrum) is endemic of Vientiane province (Vang Vieng district). In morphology of staminate flowers, it allies to B. subhowii described from southeastern Yunnan. From B. subhowii and related B. howii, new species differs in larger leaves, entire leaf margin, leaf petiole quadrate in cross section and very small, caducous inflorescence bracts. Leaf petiole quadrate in cross section, is unique character in the genus. The second species, B. tatianae (sect. Diploclinium) named after its discoverer and grower - Mrs. Tatiana Maisak, allies to B. cladotricha, B. gesneriifolia and B. hinnamnoensis originated from limestone formations associated with Hin Nam No Nature Protected Area (central Laos and Vietnam). From allied species, our plant differs in miniature habit, glabrous leaves above dark green, with large diffuse white spot (with small white crystalloid bodies), few stamens, pistillate flowers normally having 4 tepals and ovary bearing wings of distinctly unequal size. Both described species represent characteristic native element of aboriginal limestone flora of lowland karstic formations in central part of Laos.

\section{Два новых вида рода бегония (Begonia L., Begoniaceae) из центрального Лаоса}

\section{Л. В. Аверьянов ${ }^{1}$, Кхан Синь Нгуенн ${ }^{2}$ Т. В. Майсак ${ }^{1}$, Хьеп Тьен Нгуен $^{3}$, Хьеу Куанг Нгуен}

${ }^{1}$ Ботанический институт им. В. Л. Комарова РАН, ул. Проф. Попова, 2, г. Санкт-Петербург, 197376, Россия

${ }^{2}$ Институт экологии и биологический ресурсов, Академия наук и технологии Вьетнама, ул. Хоанг Куок Вьет Роад, 18, р-н Нгиа До, Кай Зяу, г. Ханой, Вьетнам.

${ }^{3}$ Центр сохранения растений Союза научно-технических организаций Вьетнама, № 25/32, линия 191, ул. Лак Лонг Куан, р-н Нгиа До, Кай Зяу, г. Ханой, Вьетнам

Ключевые слова: Лаос, локальный эндемизм, новые виды, разнообразие растений, таксономия растений, Begonia, Begoniaceae.

Аннотация. Род Begonia включает, по крайней мере, 1850 видов, большинство из которых являются узкими эндемиками. Наибольшее видовое разнообразие рода наблюдается в тропиках Америки и Азии с особо бо- 
гатой областью на территории полуострова Индокитай. Между тем инвентаризация видового богатства этой территории еще очень далека до завершения. В частности, всего лишь 20 видов рода достоверно известно к настоящему времени в Лаосе. В статье дополнительно к ним описываются еще два вида. Оба они являются узкими эндемиками. Первый вид - B. quadripetiolata (предположительно из секции Platycentrum), является эндемиком провинции Вьентьян (район Ванг Виен). По морфологии женских цветков он примыкает к B. subhowii, описанному из Южного Китая (юго-восток провинции Юньнань). От B. subhowii и родственного B. howii новый вид отличается крупными, цельнокрайними листьями, черешками листьев квадратными в поперечном сечении и маленькими, рано опадающими чешуями соцветия. Черешки листьев квадратные в сечении являются уникальным признаком среди видов рода. Второй вид - B. tatianae (секция Diploclinium), названный в честь Татьяны Майсак, нашедшей и вырастившей это растение, примыкает к B. cladotricha, B. gesneriifolia и B. hinnamnoensis, обитающим на известняках, ассоциированных с заповедной территорией Хин Нам Но (Нin Nam No) (центральная часть Лаоса и Вьетнама). От родственных видов наше растение отличается миниатюрным обликом, голыми темно-зелеными листьями с большим диффузным белым пятном (с маленькими белыми кристаллами на верхней поверхности), малым числом тычинок, женскими цветками, имеющими 4 лепестка и завязью с крыльями отчетливо неравного размера. Оба описанных вида представляют характерный элемент аборигенной флоры низкогорных карстовых формаций центральной части Лаоса.

\section{INTRODUCTION}

Begonia L. is the sixth largest genus in angiosperms (Frodin, 2004; Hughes, 2008; Hughes et al., 2015; Moonlight et al., 2018). It comprises at least 1850 species, most of which are local endemics with very restricted distribution in tropical and subtropical regions of the world. The greatest genus diversity is observed in tropical zone of America and Asia (more than 600 species each). The genus is relatively poorly presented in Africa (about 160 species) and absent in Australia (Goodall-Copestake et al., 2010). The Indochinese Peninsula in broad sense is the area of particular high diversity in Asia with about 180 species documented in China and at least 70 species in Vietnam (Shui, 2002; Nguyen T. B., 2003; Kiew, 2004, 2007; Nguyen H. Q., Tebbit, 2005, 2006; Truong, 2005; Huang, Shui, 2006; Ku et al., 2006; Peng et al., 2006, 2014; Gu et al., 2007; Kiew, 2007; Averyanov, Nguyen H. Q., 2012; Shui, Chen, 2017; Chen et al., 2018). Meanwhile, inventory of the genus species composition and diversity in some local floras of Indochina remains very far from acceptable completing. It is remarkable that species concentration on the territory of China strikingly rises in southern, southwestern and southeastern direction with maximal diversity observed in southeastern Yunnan and southwestern Guangxi in regions closely allied to Vietnam and Laos border (Gu et al., 2007). This fact gives evidence that vast areas of central Indochina should be essentially richer in Begonia species than northern territories studied much better. Numerous isolated ancient mountain formations, particularly karstic rocky remnant limestone massifs well presented in Laos undoubtedly provide home to numerous still undescribed local endemic species. Until recently, only 3 species of the genus were reported for Cambodia and 14 species for Laos (Newman et al., 2007; Hughes et al., 2015). Additionally six species were discovered in Laos in a few last years. These species are Begonia afromigrata J. J. de Wilde, B. hinnamnoensis Souvann et Lanors., B. khammouanensis Souvann. et Lamxay, B. lamxayiana Souvann., B. namkadingensis C.-J. Yang et al. and B. viscosa Aver. et H. Q. Nguyen (Hughes, 2008a, b; De Wilde et al., 2011; Averyanov, Nguyen, 2012; Hughes et al., 2015, Souvannakhoummane et al., 2016, 2018; Yang et al., 2018). Undoubtedly, this is miserable part of all species inhabiting Laos territory. Two more recently discovered species are described and illustrated below. Both are local endemics restricted in their distribution by small sporadic limestone formations found in Khammouane and Vientiane districts of central Laos.

\section{Begonia quadripetiolata Aver. et H. Q. Nguyen, sp. nov.}

Begonia sect. Platycentrum (Klotzsch) A. DC., 1859, Ann. Sei. Nat., Bot. 4, 11: 134. - Platycentrum Klotzsch, 1855, Abh. Koen. Akad. Wiss. Berlin (1854): 243.

Type: LAOS, herbarium specimens prepared in 20 III 2019. L. Averyanov, T. Maisak, LA-VN 1510/1, flowers odorless, white, anther yellow, only male flowers (holotype - LE 01049395, isotype LE 01049479).

Paratype: "LAOS, Vientiane province, Vang Vieng district, Oa Hom village, around point $19^{\circ} 06^{\prime} 52.4^{\prime \prime} \mathrm{N} 102^{\circ} 22^{\prime} 35.8^{\prime \prime} \mathrm{E}$, secondary broadleaved evergreen and semideciduous dry forest with on very steep rocky mountain slopes composed by solid marble like highly eroded limestone at 
elev. 550-650 m a. s. 1., lithophytic herb with stem $10-20 \mathrm{~cm}$ tall on shady cliffs, leaves and petioles uniform green, locally very common, 22 III 2017. L. Averyanov, N. T. Hiep, N. S. Khang, C. Q. Ngan, T. Maisak, Khamla Inkhavilay, Hongthong Southyvohanh, Pinmany Sisavath, Chanthala Cheuaysamphanh, LA-VN 1510" (LE01049628, LE01049631).

Description. Herb lithophytic, rhizomatous, stemless. Rhizome with fibrous roots, creeping, (8)10-30(35) cm long, with dark dirty-brownish persistent scales at nodes; scales (stipules) glabrous, triangular, acute to attenuate, membranaceous, (1.5)1.8-2.2(2.5) cm long, (8)10-12(14) mm wide; internodes (0.8)1.2-1.8(2.2) cm long, (1)1.2$1.6(1.8) \mathrm{cm}$ in diameter. Leaves (4)6-8(12), all basal, distichous and clustering at the apex of rhizome, petiolate, glabrous; petiole suberect, quadrate in cross section and sometimes narrowly alate, pale green to purplish at base, (14)18-28(32) cm long (4.5)5-6(7) $\mathrm{mm}$ in diameter; leaf blade asymmetric, transversely oblique broadly ovate, (6)8-12(14) cm long, (8)12-18(22) cm wide, unequally cordate at the base, herbaceous, somewhat fleshy, glabrous on both surfaces, basally 5-7-veined, veins palmate, distinct, dichotomously branching, margin entire, apex shortly attenuate; grassy velvety green on both surfaces, below little lighter. Inflorescence axillary; peduncle erect, purple, much shorter than leaves, (8)10-12(14) cm long, glabrous; flowers monosexual, pedicellate, bearing only (6)8-10(12) in dichasial cyme; bearing only pistillate flowers, tepals white, with very small, dull greenish, triangular, caducous persistent bracts at base of pedicels or dichasium branches. Staminate flowers on white to pinkish pedicel (6)12-18(22) mm long, glabrous, zygomorphic, dichlamydeous; tepals 4, sepals 2, large, broadly ovate to almost circular, (12)14-16(18) $\mathrm{mm}$ long and wide, glabrous, apex rounded, petals 2 , much smaller, elliptic, acute, (7.5)8-9(9.5) mm long, (2.4)2.6-3(3.2) mm broad; stamens numerous, brightly yellow, densely arranged on short conical axis; filaments $0.4-0.6 \mathrm{~mm}$ long, free; anthers obtriangular oblong, truncate, slightly recurved, (0.5)0.6-0.7(0.8) mm long, 0.3$0.4 \mathrm{~mm}$ wide. Pistillate flowers on pedicel $1.5-2 \mathrm{~cm}$ long, asymmetric, dichlamydeous; tepals 5, outer 3 broadly obovate, roundede at apex, (12)13.5(14) $\mathrm{mm}$ long, (10)11.5(13) $\mathrm{mm}$ wide, inner 2, as long as outer tepals, 5-6 mm wide; ovary 2(3)-loculed with axial bilamellate placentae; styles 3 , brightly yellow, 2-3 mm long, stigmatic band U-shaped, papillulose; ovary surface glabrous, unequally 3 -winged, wings broadly triangular, roundish at apex, one large (4-11 $\mathrm{mm}$ wide), two distinctly smaller (2-3 $\mathrm{mm}$ wide). Fig. 1.

Etymology. The species epithet refers leaf petioles quadrate on cross section.

Ecology, phenology and conservation status. Primary and secondary, seasonally dry, broadleaved, evergreen forests on solid highly eroded rocky crystalline limestone at elevations 550-650 $\mathrm{m}$ a. s. 1. Lithophytic herb growing in crevices of vertical shady cliffs in middle part of hill slopes. Flowers in culture April-May. Locally very common. Estimated IUCN Red List status - LC.

Distribution. Limestone areas of central Laos, Vientiane province (Vang Vieng district). Local endemic, only known from type locality.

Notes. In overall habit and floral morphology new species allies to B. subhowii S. H. Huang described from southeastern Yunnan (Malipo town area) and also recorded from Vietnam. From Begonia subhowii and closely related $B$. howii Merr. et Chun, new species differs in larger leaves (6)8$12(14) \mathrm{cm}$ long, (8)12-18(22) cm wide (vs. leaves 5-9 cm long, 10-11 cm wide), entire leaf margin (vs. leaf margin irregularly serrulate), leaf petiole quadrate in cross section and often narrowly alate (vs. petiole terete, circular in cross section) and very small, caducous inflorescence bracts, 2-4 mm long (vs. inflorescence bract persistent, much longer than $4 \mathrm{~mm}$ ). Begonia quadripetiolata is classified here provisionally in Begonia sect. Platycentrum due to the analysis of available material. It is noteworthy, that male and female flowers in our species are developed on the same plant, but on separate "male" and "female" inflorescences. Leaf petiole quadrate in cross section and formation of male and female flowers on different inflorescences, as far as we informed, are unique characters in the genus.

\section{Begonia tatianae Aver., sp. nov.}

Begonia sect. Diploclinium (Lindl.) A. DC., 1859, Ann. Sei. Nat., Bot. 4, 11: 129. - Diploclinium Lindl., 1846, Veg. Kingdom: 319.

Type: "LAOS, herbarium specimen prepared in 19 IV 2019, L. Averyanov, AL 820b.1, flowers white with light pink tint, anther and stigma bright yellow (holotype - LE01049623).

Paratype: "LAOS, Khammouane province, Boualapha district, Vang Maner village, around point $17^{\circ} 29^{\prime} 39.3^{\prime \prime} \mathrm{N}, 105^{\circ} 50^{\prime} 24.6^{\prime \prime} \mathrm{E}$, Hin Nam No Nature Protected Area, primary dry evergreen and semideciduous broad-leaved forest on very steep rocky slope near karstic hill top composed with solid, 
marble-like highly eroded limestone at $350-430 \mathrm{~m}$ a. s. 1., lithophytic herb on shady rocks near hill top, not common, 09 V 2018, L. Averyanov, Khang Sinh Nguyen, T. Maisak, Littideth Xaiyavongsa, Siphanom Keovankham, AL 820b" (LE01049002).

Description. Herb monoecious, lithophytic, rhizomatous, stemless. Rhizome with fibrous roots, very short, creeping, (1)1.5-2(2.5) cm long, densely covered by numerous, imbricate, dark brownish persistent scales; scales (stipules) glabrous, triangular, acute to apiculate, membranaceous, (4)610(12) mm long, (3.5)4-5(6) mm wide. Leaves 3-5, all basal, arranged in rosette-like cluster at the apex of rhizome, petiolate, glabrous; petiole suberect, terete, pale green to pinkish, (3.5)4-6(7) $\mathrm{cm}$ long $2-3 \mathrm{~mm}$ in diameter; leaf blade almost symmetric, reniform, (3)3.5-4(4.5) cm long, (4)5-6.5(7.5) cm wide, cordate at the base, herbaceous, somewhat fleshy, glabrous on both surfaces, basally (5)6(7)-veined, veins palmate, distinct, dichotomously branching, margin entire or slightly irregularly repand, without a distinct apex; adaxial surface dark velvety green to almost black, with large central white spot having irregularly diffuse margin, papillulate, with many small peculiar white cubic crystalloid bodies; below uniform pale green with light pink tint. Inflorescence axillary; peduncle erect, purple, much longer than leaves, (10)12-14(16) cm long, glabrous; flowers monosexual, pedicelate, (8)10-14(16) in dichasial cyme; basal pistillate; distal staminate, tepals white to light pink, with small (becoming smaller towards the tips of the inflorescence), greenish, triangular, persistent bracts at base of pedicels or dichasium branches. Staminate flowers on pedicel (4)6-14(16) mm long, glabrous, zygomorphic, dichlamydeous; tepals 4 , sepals 2 , large, broadly obovate, (6)6.5$7.5(8) \mathrm{mm}$ long, 6-6.5 mm wide, glabrous, apex rounded, petals 2 , much smaller, oblanceolate, obtuse, (4.2)4.5-5(5.2) mm long, (1.6)1.8-2.2(2.4) $\mathrm{mm}$ broad; stamens (6)7-10(12), brightly yellow, arranged on short conical axis; filaments $0.8-1 \mathrm{~mm}$ long, free; anthers obtriangular oblong, truncate, slightly recurved, (1)1.1-1.2(1.3) mm long, 0.5-0.6 $\mathrm{mm}$ wide. Pistillate flowers on pedicel (0.8)1.5$2(2.2) \mathrm{cm}$ long, asymmetric, dichlamydeous; tepals 4 , outer 3 broadly obovate, round at apex, (7.8)89(9.2) mm long, (6.8)7-7.4(4.6) $\mathrm{mm}$ wide, inner 1 elliptic, blunt, as long as outer tepals, (3.8)4(4.2) $\mathrm{mm}$ wide; ovary 3-loculed with axial bilamellate placenta; styles 3, brightly yellow, (2.4)2.6-2.8(3) $\mathrm{mm}$ long, stigmatic band U-shaped, papillulose, (1.8)2(2.2) $\mathrm{mm}$ wide at apex; ovary surface with sparse, 3-branched purple trichomes. Capsule erect or horizontally directed, broadly triangular pyramidal, (4.8)5-6(6.2) mm long, (7)8-12(13) $\mathrm{mm}$ wide (with wings), unequally 3 -winged, wings broadly triangular, roundish at apex, two large (3-4 $\mathrm{mm}$ wide), one distinctly smaller $(1.2-1.6 \mathrm{~mm}$ wide). Fig. 2.

Etymology. The species epithet honors Tatiana V. Maisak, the plant discoverer.

Ecology, phenology and conservation status. Primary, seasonally dry, broad-leaved, evergreen and semideciduous forests on solid highly eroded rocky crystalline limestone at elevations $350-450$ $\mathrm{m}$ a. s. 1. Lithophytic herb growing in crevices of vertical shady cliffs on tops and in upper part of hill slopes. Flowers in culture April-May. Not common, usually forms very small populations. Estimated IUCN Red List status - DD.

Distribution. Limestone areas of central Laos, Khammouane province (Boualapha district, northeastern part of Hin Nam No Nature Protected Area). Local endemic, only know from type locality.

Notes. New species morphologically allies to Begonia cladotricha M. Hughes, B. gesneriifolia Aver. and B. hinnamnoensis Souvann. et Lanors. originated from limestone karstic area associated with limestone formations of Hin Nam No Nature Protected Area and Quang Binh province (central Vietnam). All mentioned species belong to Begonia sect. Diploclinium sharing such diagnostic characters as a short, tuberous rhizome, stemless habit, axillary inflorescences, reniform leaves, threelocular axillary bilamellate placenta and dry winged fruit. From allied species our plant clearly differs in miniature habit with inflorescence 10-16 (vs. inflorescence $25-30 \mathrm{~cm}$ long), leaves above dark green, with large diffuse white spot, glabrous, finely papillulose, with small white crystalloid bodies (vs. leaves above pale gray-green, brown or green mottled with purple, more or less bullate, hairy at least below, without white crystalloid bodies), all parts of plant glabrous, except ovary, hairs when present stellate with three branches (vs. almost all plant hairy with scurfy or erect hairs, branched at base with 3-4 branches), number of stamens 6-12 (vs. number of stamens about 19), pistillate flowers normally with 4 tepals (vs. pistillate flowers normally with 5 tepals), 2 ovary wings large subequal, 1 wing distinctly smaller (vs. all ovary wings subequal). All four species are local endemics forming characteristic native element of aboriginal limestone flora of lowland karstic formations in central part of Laos and Vietnam. 


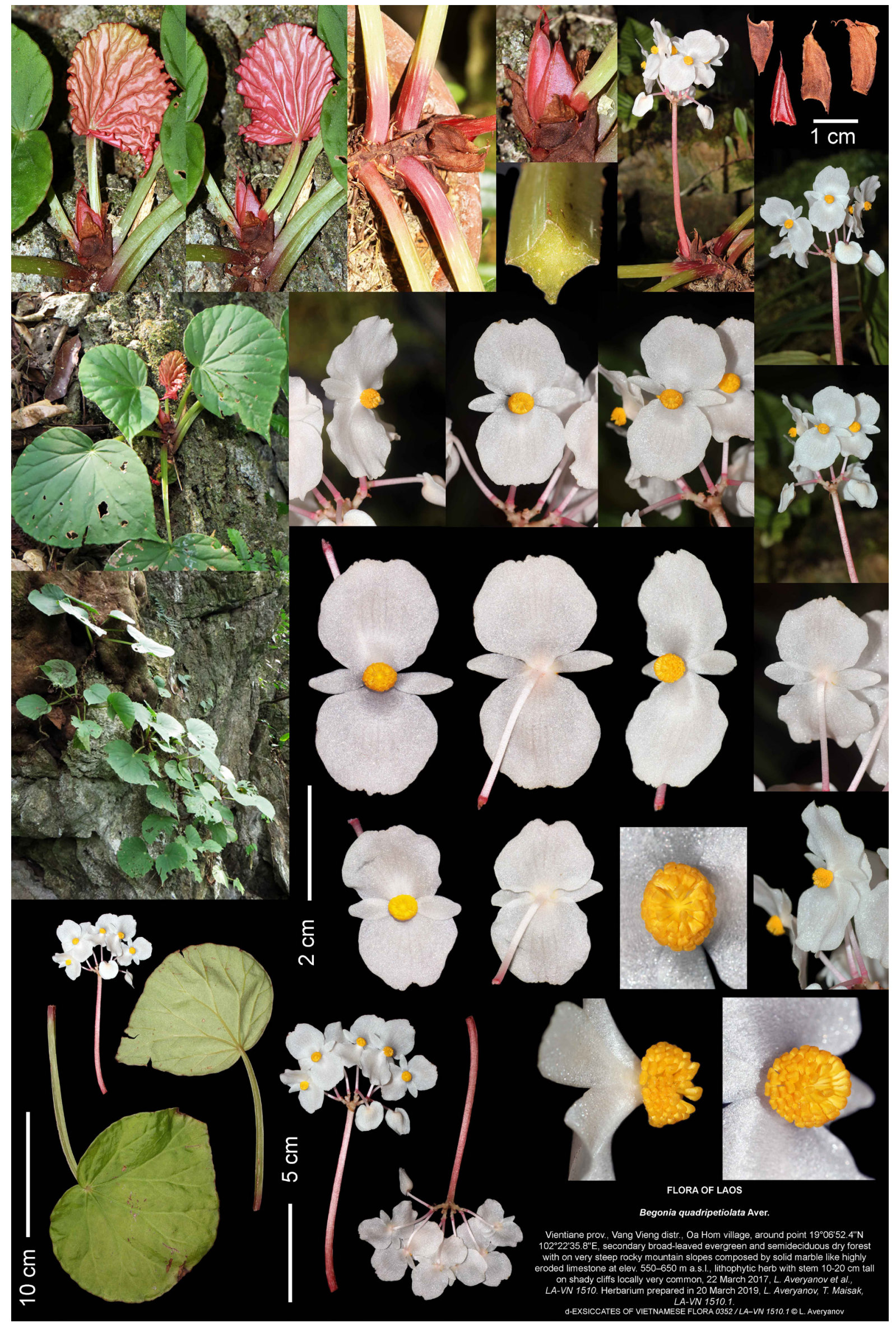

Fig. 1. Begonia quadripetiolata Aver. Digital epitype - d-EXSICCATES OF LAOTIAN FLORA 0352 / L. Averyanov, T. Maisak LA-VN 1510.1 (all photos and design by L. Averyanov and T. Maisak). 


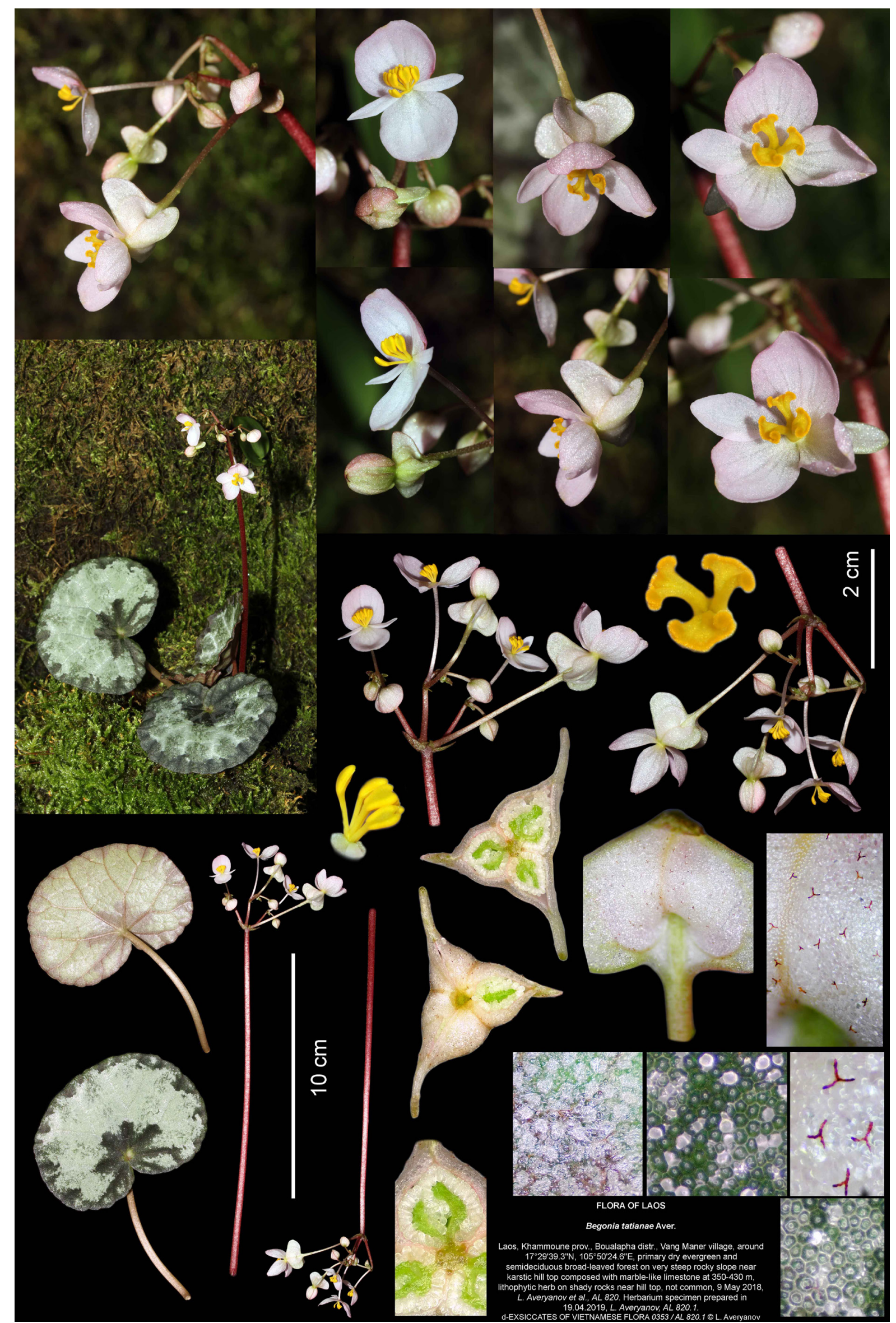

Fig. 2. Begonia tatianae Aver. Digital epitype - d-EXSICCATES OF LAOTIAN FLORA 0353 / AL 820b.1 (all photos and design by L. Averyanov and T. Maisak). 
Acknowledgments. Research fieldworks, the results of which are presented in this paper, were organized by U. S. A. National Geographic Society, grant "Assessment of plant diversity in main limestone areas of central Laos" 2016-2017 (9906-16) and Integrated Nature Conservation and Sustainable Resource Management in the Hin Nam No Region (GIZ-HinNamNo), a component of the German Development Cooperation programme Protection and Sustainable Use of Forest Ecosystems and Biodiversity (ProFEB), implemented by the Deutsche Gesellschaft für Internationale Zusammenarbeit (GIZ), GmbH. Laboratory studies were carried out in the framework of the institutional research project of the Komarov Botanical Institute of the Russian Academy of Sciences "Study of the flora of Indochina" (AAAA-A18-118031290070-6). The authors cordially thank Mrs. Petra Ebe and staff members of "Hin Nam No Nature Protected Area" associated with "Integrated Nature Conservation and Sustainable Resource Management" for their kind support in the organization and management of our fieldwork. We also thanks Mr. Chuong Quang Ngan for the plant cultivation and Dr. Van Tap Nguyen for the photography of female flowers of B. quadripetiolata.

\section{REFERENCES / ЛИTEPATУРA}

Averyanov L. V., Nguyen H. Q. 2012. Eleven new species of Begonia L. (Begoniaceae) from Laos and Vietnam. Turczaninowia 15(2): 5-32.

Chen W. H., Radbouchoom S., Nguyen H. Q., Nguyen H. T., Nguyen K. S., Shui Y. M. 2018. Seven new species of Begonia (Begoniaceae) in Northern Vietnam and Southern China. PhytoKeys 94: 65-85.

Chen-Jui Y., Shuichiro T., Phetlasy S., Norikazu O., Jer-Ming H., Tetsukazu Y. 2018. Flora of Nam Kading National Protected Area III: Begonia namkadingensis (Begoniaceae), a new species in limestone area. Phytotaxa 334(2): 195-199.

De Wilde J. J. F. E., Hughes M., Rodda M., Thomas D. C. 2011. Pliocene intercontinental dispersal from Africa to Southeast Asia highlighted by the new species Begonia afromigrata (Begoniaceae). Taxon 60(6): 1685-1692.

Frodin D. G. 2004. History and concepts of big plant genera. Taxon 53(3): 753-776.

Goodall-Copestake W., Pérez-Espona S., Harris D. J., Hollingsworth P. M. 2010. The early evolution of the mega-diverse genus Begonia (Begoniaceae) inferred from organelle DNA phylogenies. Biological journal of the Linnean society 101(2): 243-250.

Gu C. Z., Peng C.-I, Turland N. J. 2007. Begoniaceae. In: Flora of China. Eds. Z. Y. Wu, P. H. Raven, D. Y. Hong. Vol. 13. Science Press and MBG Press, Beijing and St. Louis, 153-207 pp.

Huang S. H., Shui Y. M. 2006. Begoniaceae. In: Flora Yunnanica. Ed. Wu C. Y. Vol. 12. Science Press, Beijing, $18-227 \mathrm{pp}$.

Hughes M., Hollingsworth P. M. 2008. Population genetic divergence corresponds with species level biodiversity patterns in the large genus Begonia. Molecular ecology 17(11): 2643-2651.

Hughes M. 2008a. An annotated checklist of Southeast Asian Begonia. Royal Botanic Garden Edinburgh, 176 pp.

Hughes M. 2008b. Begonia cladotricha (Begoniaceae): A new species from Laos. Edinburgh Journ. Bot. 64(1): 101-105.

Hughes M., Moonlight P., Jara A., Tebbitt M., Wilson H., Pullan M. 2015. Begonia Resource Centre. Online database available from: http://elmer.rbge.org.uk/begonia/ (Accessed 06 May 2019).

Kiew R. 2004. Begonia sizemoreae Kiew (Begoniaceae), a handsome new begonia from Vietnam. Gard. Bull. Singapore 56: $95-100$.

Kiew R. 2007. Notes on Vietnamese Begonia (Begoniaceae), including three new species. Adansonia 29(2): 229238.

Ku S. M., Liu Y., Peng C.-I. 2006. Four new species of Begonia sect. Coelocentrum (Begoniaceae) from limestone areas in Guangxi, China. Bot. Studies 47: 207-222.

Moonlight P., Ardi W. H., Padilla L. A., Chung K. F., Fuller D., Girmansyah D., Hollands R., Jara-Munoz A., Kiew R., Leong W. C., Liu Y., Mahardika A., Marasinghe L. D. K., Connor M. O., Peng C. I, Perez A. J., Phutthai T., Pullan M., Rajbhandary S., Reynel C., Rubite R. R., Sang J., Scherberich D., Shui Y. M., Tebbitt M. C., Thomas D. C., Wilson H. P., Zaini N. H., Hughes M. 2018. Dividing and conquering the fastest-growing genus: towards a natural sectional classification of the mega-diverse genus Begonia (Begoniaceae). Taxon 67(2): 267-323.

Newman M. F., Ketphanh S., Svengsuksa B., Thomas P., Sengdala K., Lamxay V., Armstrong K. 2007. A checklist of the vascular plants of Laos. Royal Botanic Garden Edinburgh, $394 \mathrm{pp}$.

Nguyen H. Q., Tebbit M. 2005. An unusual new species of Begonia (Begoniaceae) from Vietnam. Gard. Bull. Singapore 57: 247-251.

Nguyen H. Q., Tebbit M. 2006. Begonia hahiepiana, a new species of Begonia section Sphenanthera (Begoniaceae) from Vietnam. Novon 16(3): 374-377. 
Nguyen T. B. 2003. Begoniaceae Agardh. In: Danh Luc Cac Loai Thuc Vat Viet Nam (Checklist of Plant Species of Vietnam). Eds. N. T. Ban, N. K. Khoi, V. X. Phuong. Vol. 2. Agriculture Publishing House, $408-414$ pp. [In Vietnamese].

Peng C.-I., Leong W.-C., Ku S. M., Liu Y. 2006. Begonia pulvinifera (sect. Diploclinium, Begoniaceae), a new species from limestone areas in Guangxi, China. Bot. Studies 47: 319-327.

Peng C. I, Jin X. H., Ku S. M., Kono Y., Huang H. Y., Yang H. A. 2014. Begonia wuzhishanensis (sect. Diploclinium, Begoniaceae), a new species from Hainan Island, China. Botanical Studies 55: 24-30.

Shui Y. M. 2002. A new species of Begonia (Begoniaceae) from Mt. Huanglianshan of SE Yunnan, China. Acta Botanica Yunnanica 24(3): 307-308.

Shui Y. M., Chen W. H. 2017. Begonia of China. Yunnan Science and Technology Press, 285 pp.

Souvannakhoummane K., Hughes M., Lanorsavanh S. 2016. Begonia lamxayiana Souvann. (Begoniaceae): a new species from Lao PDR. Thai Journal of Botany 8(1): 1-5.

Souvannakhoummane K., Lanorsavanh S., Lamxay V. 2018. Two new species of Begonia L. (Begoniaceae) from central Laos. Taiwania 63(3): 188-194.

Truong Q. T., Kiew R., Vermeulen J. J. 2005. Begonia bataiensis Kiew, a new species in Section Leprosae (Begoniaceae) from Vietnam. Gard. Bull. Singapore 57: 19-23.

Yang C.-J., Tagane S., Souladeth S., Okabe N., Hu J.-M., Yahara T. 2018. Flora of Nam Kading National Protected Area III: Begonia namkadingensis (Begoniaceae), a new species in limestone area. Phytotaxa 334(2): $195-199$. 